\title{
Structure and composition of trees in Mount Tilu Nature Reserve, West Java, Indonesia
}

\author{
TRI CAHYANTO ${ }^{1, \bullet}$, MUHAMMAD EFENDI ${ }^{2, \bullet \bullet}$, DIAN MUHAMAD RAMDAN ${ }^{1}$ \\ ${ }^{1}$ Department of Biology, Faculty of Science and Technology, Universitas Islam Negeri Sunan Gunung Djati Bandung. Jl. A.H. Nasution No. 105, Cibiru, \\ Bandung 40614, West Java, Indonesia. Tel.: +62-22-7800525, `email: tri_cahyanto@uinsgd.ac.id; \\ ${ }^{2}$ Cibodas Botanic Gardens, Research Centre for Plant Conservation and Botanic Gardens, Indonesian Institute of Sciences. Jl. Kebun Raya Cibodas, \\ Sindanglaya, Cianjur 43253, West Java, Indonesia. Tel. +62-263-512233, ^•email: muhammadefendi05@ gmail.com
}

Manuscript received: 22 March 2020. Revision accepted: 20 May 2020.

\begin{abstract}
Cahyanto T, Efendi M, Ramdan DM. 2020. Structure and composition of trees in Mount Tilu Nature Reserve, West Java, Indonesia. Biodiversitas 21:2674-2680. An understanding of the structure and composition of stands in a conservation area is needed to support sustainable management strategy. However, this information in the Mount Tilu Nature Reserve, Bandung District, West Java area is still lacking. This research was aimed to analyze the structure and composition of tree species in the block of Malagembol forest, Mt. Tilu NR. Data collection was carried out through vegetation analysis using sampling plot method with size of $10 \times 100 \mathrm{~m}^{2}$ at threelevel altitudes of $1530 \mathrm{~m}, 1745 \mathrm{~m}$, and $1950 \mathrm{~m}$ asl. Observation parameters included species names, number of individuals, and diameter at breast height (dbh). Data were analyzed to determine the floristic composition, species structure based on their diameter class, relative basal area, diversity indices, and analysis of the importance of the main components of trees species through Principal Component Analysis (PCA). A total of 32 tree species from 23 families was found in the observation plots which was dominated by Fagaceae, Lauraceae, and Myrtaceae families. Some pioneer plants covered the gap in vegetation due to minor disturbance and residual damage in the past. Nonetheless, the dominance of stands with small diameters indicated good regeneration status following such disturbance. Based on these findings, we recommend protecting the vegetation in Mt. Tilu NR by limiting community activities that can disturb the forest.
\end{abstract}

Keywords: Biodiversity, mountain forest, species richness, tree density, tree basal area

\section{INTRODUCTION}

Mount Tilu Nature Reserve (Mt. Tilu NR) is located in two subdistricts, namely Pasirjambu Subdistrict and Pangalengan Subdistrict, Bandung District, West Java Province, Indonesia. It is the second-largest nature reserve in West Java after Mt. Simpang NR, which is directly adjacent to the area. Initially, the area covered 8,000 ha based on the Minister of Agriculture Decree No. 68/Kpts/U/2/1978 dated 7 February 1978. In its development, based on the Minister of Forestry Decree No. SK.1873/Menhut-VII/KUH/2014 dated 25 March 2014, the area has been reduced to 7,479.80 ha.

Ecologically, Mt. Tilu NR plays an important role in the hydrological cycle of Bandung District and its surrounding areas. In addition, Mt. Tilu NR is a habitat for Javanese endemic primates, such as Javan Gibbon (Hylobates moloch), Lutung (Trachypithecus auratus) and Javan Surili (Presbytis comata), as well as important places to conserve the flora of mountain forests of Java, such as Castanopsis argentea, Lithocarpus sundaicus, Litsea javanica and Schima wallichii (Susilo 2018).

Similar with other mountain forest ecosystems in Java, the forest ecosystem in Mt. Tilu NR is threatened by environmental damage (Purwaningsih et al. 2017; Rosleine 2014; Sulistyawati et al. 2018; Cahyanto et al. 2019). The location of the forest is directly adjacent to plantation and community forest, allowing a unique mix of vegetation composition in the area, as found in the Cibodas Biosphere Reserve forest (Mutaqien and Zuhri 2011). However, because of this position, there is a risk of alien plant species invasion which has the potential to change the composition and structure of the natural forest vegetation (Zuhri and Mutaqien 2013; Junaedi and Dodo 2014).

Understanding the structure and composition of tree vegetation is one of the parameters that must be considered in the management of conservation forest areas (Laumonier et al. 2010; Kusmana 2011; Zhu et al. 2015). This is particularly important for several reasons. First, some tree species have important economic value which makes them under pressure due to over-exploitation, leaving them vulnerable to population extinction in their natural habitat (Budiharta et al. 2011). Second, information about tree structure can provide insight on regenerative ability of the stand in a forest area, both in present time and in the future (Laumonier et al. 2010; Mongabay 2013; Prawiroatmodjo and Kartawinata 2014; Ifo et al. 2016; de Carvalho et al. 2017; Henry et al. 2017; Manral et al. 2018; Siregar and Undaharta 2018; Salvana et al. 2019). Third, tree community is the largest contributor of above-ground biomass in tropical forests (Slik et al. 2010; Feldpausch et al. 2012). Forth, tree vegetation also provides various ecosystem services (Sekercioglu 2010; Lindenmayer et al. 2012), habitat of biodiversity (Myers et al. 2000; Hrdina and Romportl 2017) and potential use for bioprospecting 
(Harvey and Gericke 2011; Senthilkumar and Murugesan 2012).

Until now, information on the condition of vegetation in Mt. Tilu NR is still lacking. Previously, Susilo (2018) conducted research on the association of some species in the Mt. Tilu, and Cahyanto et al. (2018) investigated trees that host orchids in the block of Gambung. Therefore, this research was focused on the vegetation in the block of Malagembol, which was not included in the previous studies. The aims of the study were to identify the diversity, floristic composition, and structure of trees species in the block of Malagembol, Mt. Tilu NR. The results of this study can serve as baseline information when developing conservation strategies and management of the nature reserve.

\section{MATERIALS AND METHODS}

\section{Study area and period}

The study was conducted along the climbing route in the block of Malagembol, Mt. Tilu NR, Bandung District, West Java Province at the altitude of 1500 to 2100 meters above sea level (m asl.) (Figure 1). The research location has hilly terrain with slope reaching $75^{\circ}$ and temperature of $20.2-26.8^{\circ} \mathrm{C}$, air humidity up to $90 \%$, soil $\mathrm{pH} 6.0-7.2$, and light intensity of 75-4490 lux (field data). Data collection period lasted for two months, from April 2019 to May 2019.

\section{Data collection}

Data collection on the structure and composition of trees was carried out through vegetation analysis using sampling plot method. A plot with size of $10 \times 100 \mathrm{~m}^{2}$ was made at each level altitudes, i.e. $1530 \mathrm{~m}$ asl, $1745 \mathrm{~m}$ asl, and $1950 \mathrm{~m}$ asl. Each plot was divided into 10 subplots of $10 \times 10 \mathrm{~m}^{2}$ to record all trees within the plot. We defined tree as woody plant with a single stem with diameter at breast height (dbh) of more than $10 \mathrm{~cm}$ and minimum of two meters in height, excluding tree fern, bamboo, and palm (Beech et al. 2017). Observation parameters, i.e. scientific names, local names, number of individuals, and $\mathrm{dbh}$, were recorded. The scientific name and taxa group referred to the Angiosperm Phylogeny Group classification (The Angiosperm Phylogeny Group 2016), the Plantlist database (http://www.theplantlist.org/) and the Powo science (http://www. plantsoftheworldonline.org/).

\section{Data analysis}

Data were analyzed to determine the floristic composition and structure including relative basal area, species richness, and tree diversity indices. The following statistical analyses were conducted using $R$ programme $(R$ Core Team 2017). Multivariate analysis through Principal Component Analysis (PCA) was used to analyze the importance of the tree in the forest community using the package of "FactoMineR" (Lê et al. 2008) and "factoextra" (Kassambra and Mundt 2017). Tree diversity indices, i.e. rarefied richness, Shannon-Wiener and Simpsons, were computed using "vegan" package (Oksanen et al. 2017).

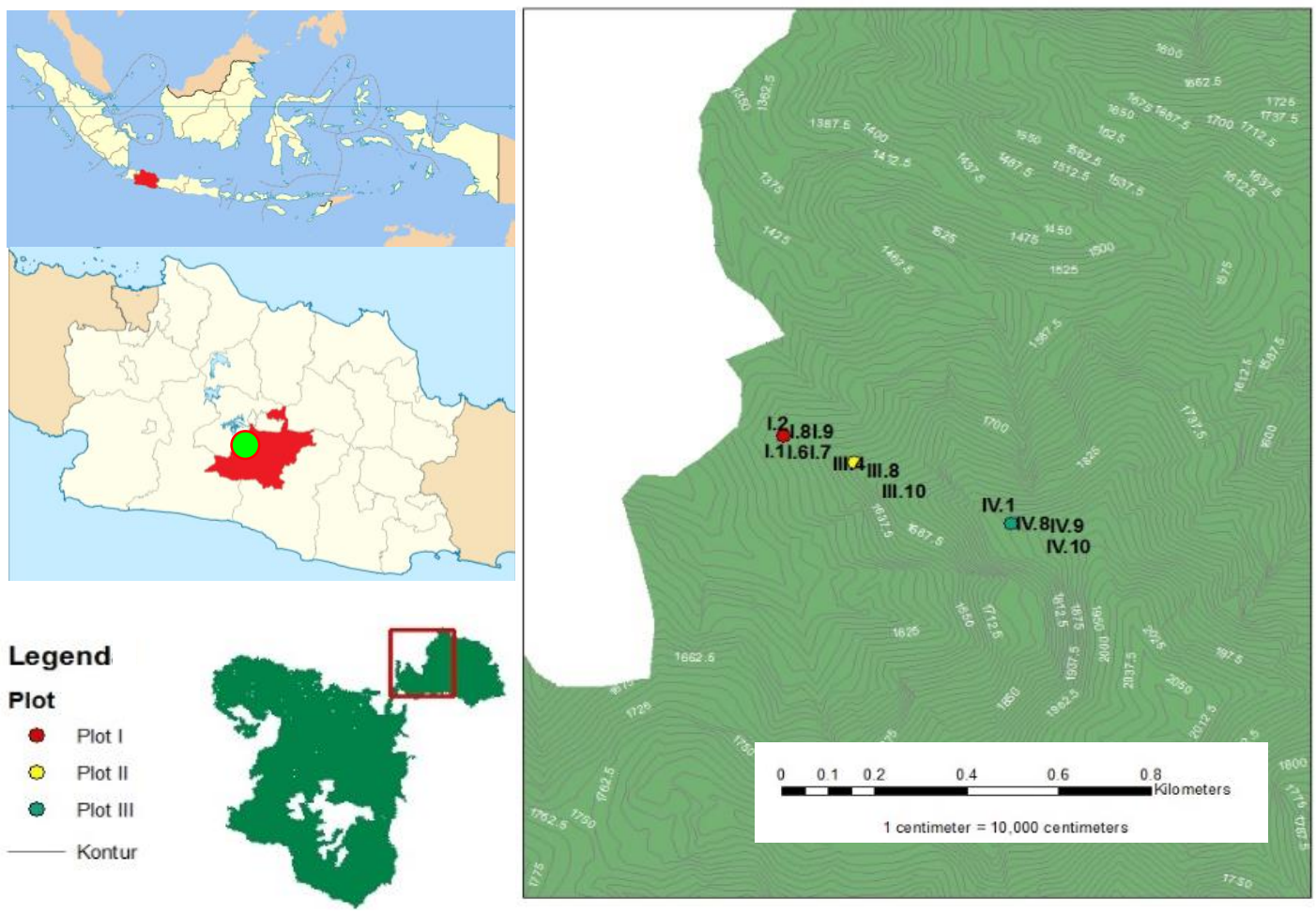

Figure 1. Research location at the block of Malagembol, Mt. Tilu Nature Reserve, Bandung, West Java, Indonesia 


\section{RESULTS AND DISCUSSION}

The dominance of Fagaceae in the block of Malagembol

A total of 32 species of trees belonging to 23 families was successfully identified in the study area. Castanopsis javanica and Quercus gemelliflora were the most abundant species across all plots (Figure 2). Other mountain trees species, i.e. Syzygium acuminatissimum, Schima wallichii, Lithocarpus pseudomoluccus, and Elaeocarpus angustifolius, were also found in the area. One species of gymnosperms, i.e. Podocarpus neriifolius, was found at an altitude of $1950 \mathrm{~m}$ asl. The list of the species recorded were angiosperm trees widely distributed in Java (Junaedi and Mutaqien 2010; Rozak et al. 2016; Purwaningsih et al. 2017). Although the composition at species level differs from Susilo (2018), similar trend in the dominance of Fagaceae-Lauraceae was found in both studies.

The composition of trees from the Fagaceae, Myrtaceae, and Lauraceae families is one of the characteristics of mountain rain forests. These plant species formations dominate forest vegetation, especially in the submontane to montane zones (Culmsee et al. 2010; Culmsee et al. 2011; Sadili et al. 2018). Two species of Fagaceae, i.e. C. javanica and $Q$. gemelliflora, were found to have a wide distribution from lowland to an altitude of $2000 \mathrm{~m}$ asl (Fujii et al. 2006). Particularly C. javanica, the species is able to grow on various types of vegetation in Mt. Gede Pangrango National Park (Rozak et al. 2016) and is the dominant species in Mt. Patuha forest (Junaedi and Mutaqien 2010).

The number of tree species in the block of Malagembol is higher than that in the study by Susilo (2018) which was done in a permanent plot with size $100 \times 100 \mathrm{~m}^{2}$ in Mt. Tilu NR (Table 1). Four species, i.e. Altingia excelsa, $Q$. gemelliflora, Schima wallichii, and Neolitsea javanica, were found in both studies (Susilo (2018). Furthermore, Lithocarpus pallidus, Ficus fistulosa, Phobea grandis, Castanopsis cuspidata, and Trema amboinensis, were reported by Cahyanto et al. (2018). Floristic compositions are thought to be related to habitat conditions, soil conditions, topography, distance between locations, altitude, and the number of samples and the sampling techniques used (Coomes and Allen 2007; Baraloto et al. 2013; Rozak and Gunawan 2015; Chian et al. 2016; Salvana et al. 2019).

Pioneer tree species were also found in the study area including Macaranga rhizinoides, Schima wallichii, Ostodes paniculata, and Viburnum sambucinum. These plant species covered the gaps in the forest due to fallen trees, landslides, and windstorms. These species are more tolerant of light compared to the native species (Mutaqien and Zuhri 2011; Goodale et al. 2012; Rosleine et al. 2014; Mulyana and Kusmana 2017).

\section{Good regeneration status of trees in the block of Malagembol}

The average tree density reached 450 trees/ha and tended to increase along with the increase in altitude of the location, namely plot 1 , plot 2 , and plot 3 reached 340,490 and 520 trees/ha, respectively. Conversely, tree size tended to decrease with increasing altitude which is in line with the other studies as reported by Culmsee et al. (2010), Reddy et al. (2010), and Coomes and Allen (2007). In addition to altitude (Rozak and Gunawan 2015), light competition and nutrient composition influence tree density (Coomes and Allen 2007; Wagner et al. 2011). Besides the higher density, the species composition at higher altitudes was also more homogeneous, especially in Plot 3. This shows the ability of adaptation of plant species to the environment is very limited (Arrijani 2008).

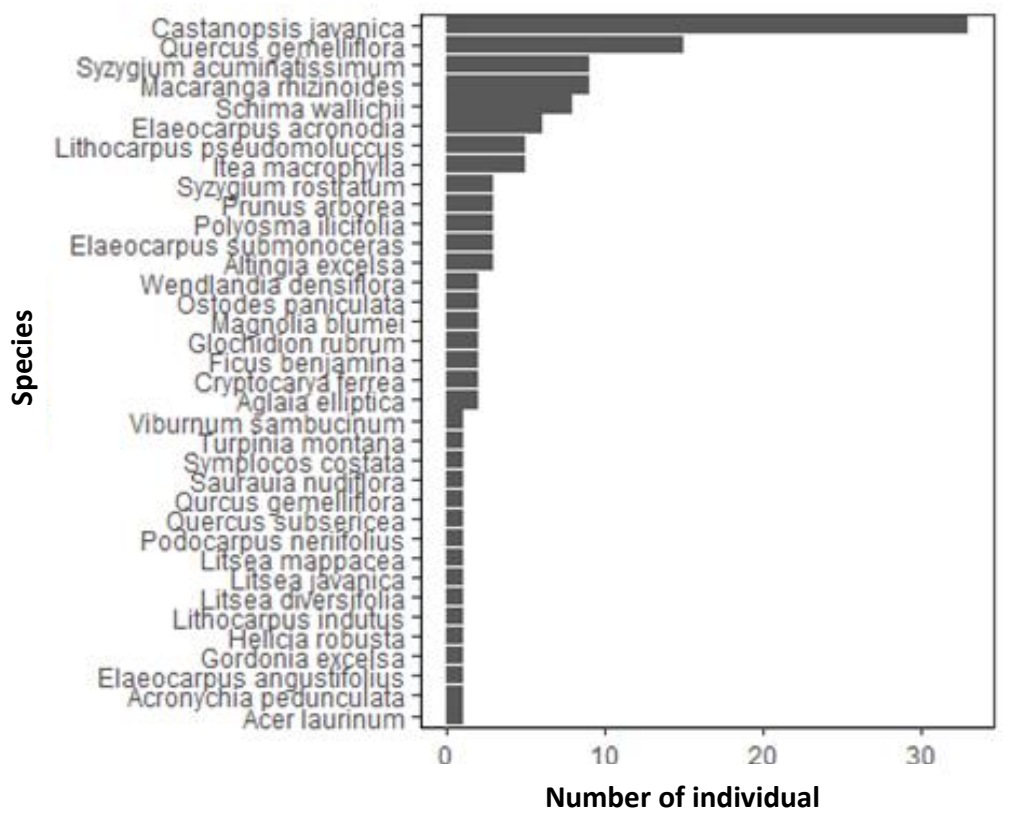

Figure 2. Species name and individual number of trees in the block of Malagembol forest, Mt. Tilu, Bandung, West Java, Indonesia 
Table 1. Composition of trees in the Mt. Tilu NR forest, Bandung, West Java, Indonesia

\begin{tabular}{|c|c|c|c|c|}
\hline Name of tree & Local name & Family & This research & Susilo (2018) \\
\hline Acer laurinum Hassk. & Huru bodas & Sapindaceae & + & - \\
\hline Acronychia pedunculata Zoll \& Moritzi & Ki jeruk & Rutaceae & + & - \\
\hline Aglaia elliptica (C.DC.) Blume & Tanglar & Meliaceae & + & - \\
\hline Altingia excelsa Noronha & Rasamala & Altingiaceae & + & + \\
\hline Antidesma montanum Blume. & Ki huut & Phyllanthaceae & - & + \\
\hline Castanopsis acuminatissima (Blume) A.DC & Ki riyung & Fagaceae & - & + \\
\hline Castanopsis argentea (Blume) A.DC & Saninten & Fagaceae & - & + \\
\hline Castanopsis javanica (B1.) A.DC & Ki hiur & Fagaceae & + & - \\
\hline Cryptocarya ferrea $\mathrm{Bl}$. & Huru mentek & Lauraceae & + & - \\
\hline Elaeocarpus angustifolius $\mathrm{Bl}$. & Janitri & Elaeocarpaceae & + & - \\
\hline Elaeocarpus punctatus Wall. ex Mast. & Huru cangkring & Elaeocarpaceae & + & - \\
\hline Ficus cf. benjamina L. & Beringin & Moraceae & + & - \\
\hline Ficus hispida L.f. & Beunying & Moraceae & - & + \\
\hline Ficus padana Burm.f. & Hamberang & Moraceae & - & + \\
\hline Ficus vasculosa Wall. ex Miq. & Kuray & Moraceae & - & + \\
\hline Glochidion rubrum $\mathrm{Bl}$. & $\mathrm{Ki}$ pare & Phyllanthaceae & + & - \\
\hline Gordonia excelsa (Blume) Blume & Ki sapi & Theaceae & + & - \\
\hline Helicia robusta (Roxb.) R.Br. ex Blume & Kendung & Proteaceae & + & - \\
\hline Itea macrophylla Wall. & Kanyere badak & Iteaceae & + & - \\
\hline Lithocarpus pseudomoluccus (Blume) Rehder & Pasang jambe & Fagaceae & + & - \\
\hline Lithocarpus sundaicus (Blume) Rehder & Pasang & Fagaceae & - & + \\
\hline Litsea accedentoides Kood. \& Valeton* & Huru & Lauraceae & - & + \\
\hline Litsea diversifolia $\mathrm{Bl}$. & Huru Kisereh & Lauraceae & + & - \\
\hline Litsea mappacea Boerl. & - & Lauraceae & + & - \\
\hline Macaranga rhizinoides (B1.) Müll.Arg. & Manggong & Euphorbiaceae & + & - \\
\hline Magnolia sumatrana (Miq.) Figlar \& Noot. & Baros & Magnoliaceae & + & - \\
\hline Neolitsea javanica (Blume) Backer & Huru batu & Lauraceae & + & + \\
\hline Ostodes paniculata $\mathrm{Bl}$. & Mumuncangan & Euphorbiaceae & + & - \\
\hline Podocarpus neriifolius D.Don & Jamuju & Podocarpaceae & + & - \\
\hline Polyosma illicifolia $\mathrm{B1}$. & $\mathrm{Ki}$ apu & Escalloniaceae & + & - \\
\hline Prunus arborea (B1.) Kalkman & Kawoyang & Rosaceae & + & - \\
\hline Quercus gemelliflora Blume & Huru batu & Fagaceae & + & + \\
\hline Quercus lineata Blume & Pang gebod & Fagaceae & - & + \\
\hline Saurauia nudiflora A.DC & Ki leho & Actinidiaceae & + & - \\
\hline Schefflera aromatica (Blume) Harms. & Manggong & Araliaceae & - & + \\
\hline Schima wallichii Choissy & Puspa & Theaceae & + & + \\
\hline Symplocos costata Choisy ex Zoll. & Jirak & Symplocaceae & + & - \\
\hline Syzygium acuminatissimum (B1.) A.DC & Ki tambaga & Myrtaceae & + & - \\
\hline Syzygium rostratum (B1.) A.DC & Ki heas & Myrtaceae & + & - \\
\hline Syzygium sp. & Cerem & Myrtaceae & - & + \\
\hline Turpinia montana (Blume) Kurz & Ki tulang & Staphyleaceae & + & - \\
\hline Viburnum sambucinum Reinw. ex Blume & Benteur & Adoxaceae & + & - \\
\hline Wendlandia densiflora (B1.) A.DC & - & Rubiaceae & + & - \\
\hline
\end{tabular}

Note: $(+)=$ found in observation area, $(-)=$ not found in observation area

The horizontal structure of stands based on diameter class showed trees with small diameters tended to have higher density compared to the large trees (Figure 3.A). This reverse $\mathrm{J}$-shaped diameter distribution indicates good regeneration status of tree species in the area which has similar condition with some mountain forests in Java, including Mt. Gede Pangrango (Arrijani 2008), Mt. Wilis (Purwaningsih et al. 2017) and Mt. Burangrang (Cahyanto et al. 2019). However, very large trees with dbh of more than $50 \mathrm{~cm}$ were not found in this study. The dominance of small trees in the block of Malagembol forest is likely due to illegal logging, farming activity, and natural disturbances (Kelman 2013; Tsujino et al. 2016; Austin et al. 2019).
Cumulatively, $C$. javanica, and $Q$. gemelliflora contributed the highest relative basal area due to the abundant number of individuals. However, it is different from $A$. excelsa in which despite the small number of individuals, it had a relatively high basal area due to the large size of the tree in terms of diameter. In the Cibodas mountain forest, the three species are categorized as emergent trees, having large diameter with tree height reaching $80 \mathrm{~m}$ and up to hundreds of years in age (Zuhri et al. 2018). The dominance of small trees (i.e. trees with dbh $<40 \mathrm{~cm}$ ) in the block of Malagembol is an indication of primary succession, but it has not been climax yet (Arrijani 2008; Mansur et al. 2017). 

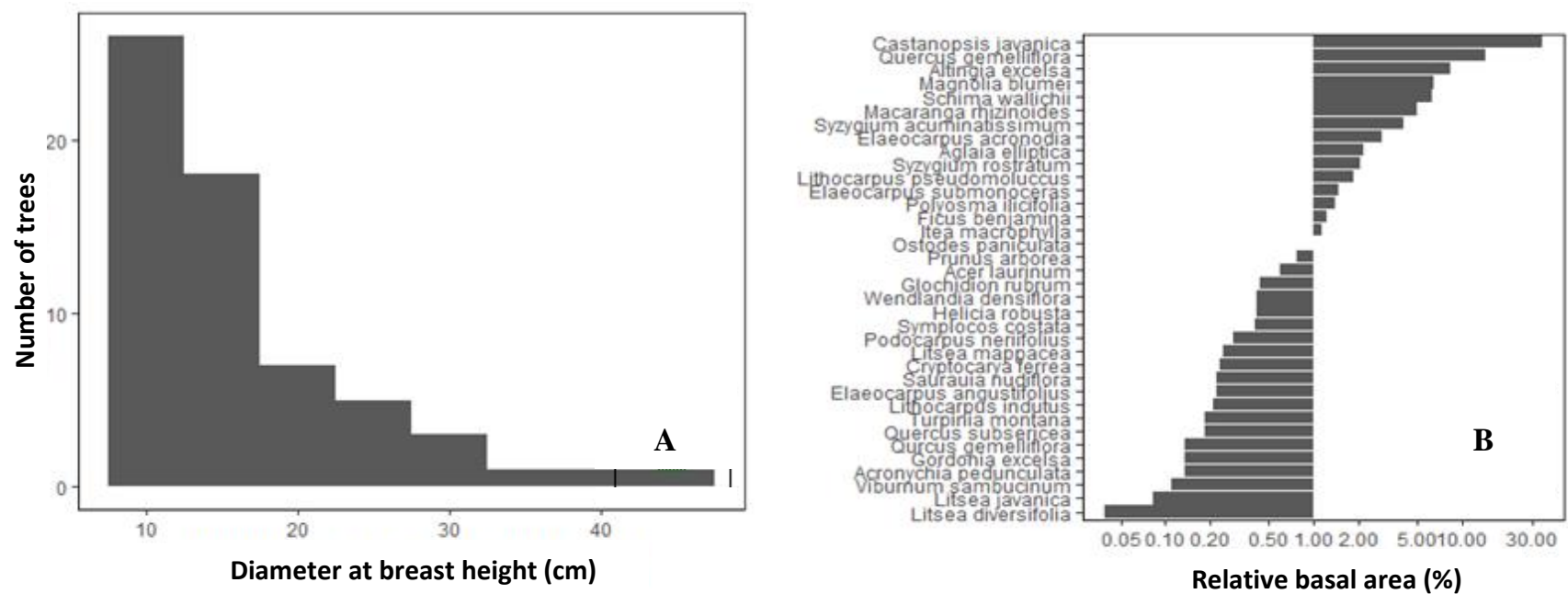

Figure 3. The structure of vegetation based on: A. dbh class; B. Relative basal area

\section{Tree diversity in the block of Malagembol}

Tree diversity in Plot 2 was much higher than that in Plots 1 and 3 (Table 2). While we found Plot 1 was more diverse than Plot 3 in terms of rarefied richness and Shannon-Wiener indices, we found the Simpson index of Plot 1 was slightly lower than Plot 3 (Table 2). The difference of those indices perhaps due to the limited number of plots as shown in the rarefaction curve (Figure 4). In general, the level of tree diversity in Mt. Tilu was lower than that in Mt. Wilis, East Java, which was conducted at an altitude of $1500 \mathrm{~m}$ asl (Purwaningsih et al. 2017). The differences in diversity indices among forests are thought to be related to habitat conditions and disturbance levels.

Based on the PCA, the variation of trees composition in the block of Malagembol only explains $45.1 \%$ of all variations composition in the dimension I and dimension II (Figure 5). The low contribution of factor to the variation in our study site is perhaps due to the limited number of the plot area. This is supported by the fact that species richness based on rarefaction curves is still increasing along with the number of sample sizes (i.e. not reach a steady-state) (Figure 4). This finding suggests that we need more plots in order to capture a more accurate result in the variation of the forests. Two species, i.e. Castanopsis javanica and $Q$. gemelliflora, have a high contribution in arranging stands, supported by the dominance of the number of individuals and their basal area (Figure 3.B).

Table 2. Tree diversity indices in the block of Malagembol, Mt. Tilu NR, West Java

\begin{tabular}{lccc}
\hline & Plot 1 & Plot 2 & Plot 3 \\
\hline Rarefied richness & 16 & 19 & 15 \\
Shannon-Wiener & 2.45 & 2.54 & 2.32 \\
Simpson & 0.87 & 0.89 & 0.88 \\
\hline
\end{tabular}

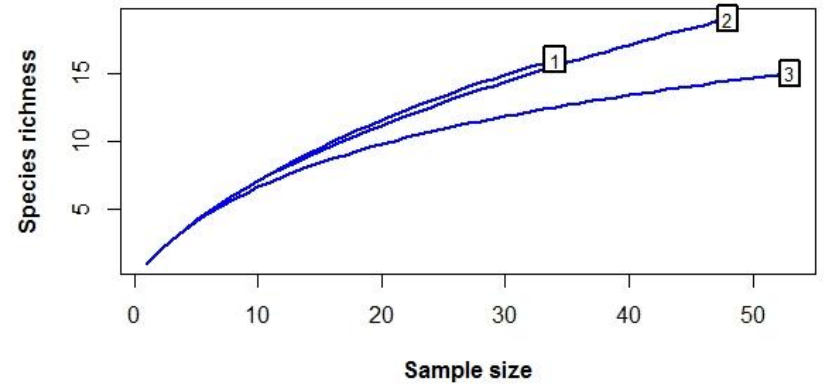

Figure 4. The curve of species richness based on rarefaction curve in the block of Malagembol, Mt. Tilu, Bandung, West Java, Indonesia

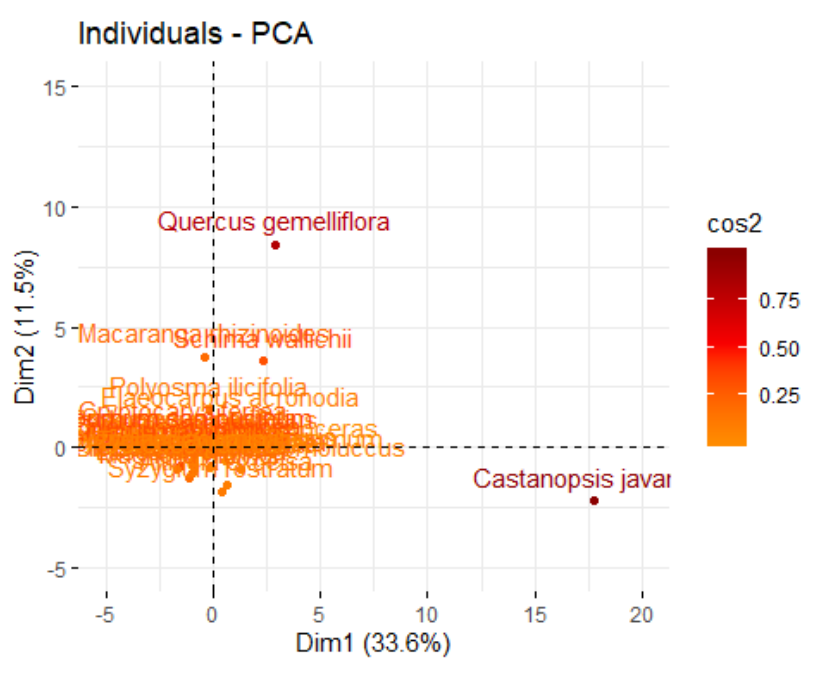

Figure 5. PCA analysis of the type of forest stand in Block Malagembol, Mt. Tilu, Bandung, West Java, Indonesia 
In conclusion, the dominance of Fagaceae family in the block of Malagembol, Mt. Tilu NR is in accordance with the floristic composition of other mountain forests in Java. Castanopsis javanica and Q. gemelliflora have the highest contribution in arranging this formation, both in individual number and relative basal area. The presence of pioneer plants and the dominance of small trees showed good regeneration status in Mt. Tilu following previous vegetation disturbances, which are probably due to natural disturbance and illegal logging some decades ago.

\section{ACKNOWLEDGEMENTS}

We would like to thank the Head of BKSDA of West Java for granting permission in the study. Thank you also to: Muslim (Cibodas Botanic Gardens, LIPI) who has assisted field sampling and helping in the identification of plants; Dedi Rustandi (Mt. Tilu NR), Abdul Halim (Mt. Tilu NR), and Julham Affandi Tarigan (Mt. Tilu NR) who have assisted on field sampling activity. We greatly appreciate our supervisor Dr. Andes Hamuraby Rozak (Center for Plant Conservation and Botanic Gardens, LIPI) for his advice, guidance, and encouragement throughout this study.

\section{REFERENCES}

Arrijani A. 2008. Vegetation structure and composition of the montane zone of Mount Gede Pangrango National Park. Biodiversitas 9 (2): 134-141.

Austin KG, Schwantes A, Gu Y, Kasibhatla P. 2019. Whats causes deforestation in Indonesia? Environ Res Lett 14 (2019): 024007.

Baraloto C, Paine CET, Patiño S, Bonal D, Herault B, Chave J. 2013. Functional trait variation and sampling strategies in species-rich plant communities. Funct Ecol 24: 208-216.

Beech E, Riversa M, Oldfield S, Smith PP. 2017. Global Tree Search: The first complete global database of tree species and country distributions. J Sustain For 36 (5): 454-489.

Budiharta S, Widyatmoko D, Irawati, et al. 2011. The processes that threaten Indonesian plants. Oryx 45 (2): 172-179.

Cahyanto T, Efendi M, Shofara RM, Dzakiyyah M, Nurlaela, Satria PG 2019. Short Communication: Floristic survey of vascular plant in the submontane forest of Mt. Burangrang Nature Reserve, West Java, Indonesia. Biodiversitas 20 (8): 2197-2205.

Cahyanto T, Paujiah E, Yuliandiana V. 2018. Anggrek epifit di Kawasan Konservasi Cagar Alam Gunung Tilu, Jawa Barat: Komposisi spesies dan jenis pohon inangnya. Bioma 7 (1): 82-94. [Indonesian].

Chian YS, Yeh CL, Wang CC. 2016. Variation in mountain vegetation composition between the east and west sides of Southern Taiwan. Forests 179 (7): 1-13

Coomes DA, Allen RB. 2007. Effects of size, competition and altitude on tree growth. J Ecol 95 (5): 1084-1097.

Culmsee H, Leuschner C, Moser G, Pitopang R. 2010. Forest aboveground biomass along an elevational transect in Sulawesi, Indonesia, and the role of Fagaceae in tropical montane rain forests. $\mathrm{J}$ Biogeogr 37: 960-974.

Culmsee H, Pitopang R, Mangopo H, Sabir S. 2011. Tree diversity and phytogeographical patterns of tropical high mountain rain forests in Central Sulawesi Indonesia. Biodivers Conser 20: 1103-1123.

de Carvalho AL, d'Oliveira MVN, Putz FE, de Oliveira LC. 2017. Natural regeneration of trees in selectively logged forest in western Amazonia. For Ecol Manag 392: 36-44.

Feldpausch TR, Lloyd J, Lewis SL, et al. 2012. Tree height integrated into pantropical forest biomass estimates. Biogeoscience 9: 3381-3403.
Fujii S, Nishimura S, Yoneda T. 2006. Altitudinal distribution of Fagaceae in West Sumatra. Tropics 15 (2): 153-163.

Goodale UM, Ashton MS, Berlyn GP, Gregoire TG, Singhakumara BMP, Tennakoon KU. 2012. Disturbance and tropical pioneer species: patterns of association across life-history stages. For Ecol Manag 277: 54-66.

Harvey AL, Gericke N. 2011. Bioprospecting: Creating a Value for Biodiversity. In I. Pavlinov (Ed.), Research in Biodiversity-Models and Applications. InTech, Rijeka, Croat.

Henry RC, Palmer SCF, Watts K, Mitchell RJ, Atkinson N, Travis JMJ. 2017. Tree loss impact on ecological connectivity: Developing model for assessment. Ecol Informatics 42 (2017): 90-99.

Hrdina A, Romportl D. 2017. Evaluating global biodiversity hotspots-very rich and even more endangered. J Landsc Ecol 10 (1): 108-115.

Ifo SA, Moutsambote JM, Koubouana F, Yoka J, Ndzai SF, BouetouKadilamio LNO, Mampouya H, Jourdain C, Bocko Y, Mantota AB, Mbemba M, Mouanga-Sokath D, Odende R, Mondzali LR, Wenina YEM, Ouissika BC, Joel LJ. 2016. Tree Species Diversity, Richness, and Similarity in Intact and Degraded Forest in the Tropical Rainforest of the Congo Basin: Case of the Forest of Likouala in the Republic of Congo. Intl $\mathbf{J}$ For Res 2016: 1-12. DOI: $10.1155 / 2016 / 7593681$

Junaedi DI, Dodo. 2014. Exotic plants in Halimun Salak corridor: Microenvironment, detection and risk analysis of invasive plants. Biotropia 21 (1): 38-52.

Junaedi DI, Mutaqien Z. 2010. Diversity of tree communities in Mount Patuha Region, West Java. Biodiversitas 11 (2): 75-81.

Kassambara A, Mundt F. 2017. Extract and Visualize the Results of Multivariate Data http://www.sthda.com/english/rpkgs/factoextra.

Kelman CC. 2013. Governance lessons from two Sumatran integrated conservation and development projects. Conserv Soc 11 (3): 247-263.

Kusmana C. 2011. Forest resources and forestry in Indonesia. For Sci Technol 7 (4): 155-160.

Laumonier Y, Uryu Y, Stuwe M, Budiman A, Setiabudi B, Hadian O. 2010. Eco-floristic sectors and deforestation threats in Sumatra: identifying new conservation area network priorities for ecosystembased land use planning. Biodivers Conserv (2010) 19:1153-1174.

Le S, Josse J, Husson F. 2008. FactoMineR: An R Package for Multivariate Analysis. J Statistical Software 25 (1): 1-18

Lindenmayer DB, Laurance WF, Franklin JF. 2012. Global decline in large old trees. Science 338 (6112): 1305-1306.

Manral V, Padalia K, Karki H. 2018. Plant diversity and regeneration potential of three different forests of Central Himalaya. Curr World Environ 13 (1): 113

Mansur M, Kartawinata K. 2017. Phytosociology of a lower montane forest on Mt. Batulanteh, Sumbawa, Indonesia. Reinwardtia 16 (2): 77-92.

Mongabay DG. 2013. Tree regeneration in a subtropical humid forest: Effect of cultural disturbance on seed production, dispersal and germination. J Appl Ecol 33: 1551-1560.

Mulyana D, Kusmana C. 2017. Species and structure compopsition of nature disturbed forest stand in Papandayan Mountain, West Java Indonesia. Intl J Sci 31 (2): 286-296.

Mutaqien Z, Zuhri M. 2011. Establishing a long-term permanent plot in remnant forest of Cibodas Botanic Garden, West Java. Biodiversitas 12 (4): 218-224.

Myers N, Mittermeier RA, Mittermeier CG, da Fonseca GAB, Kent J. 2000. Biodiversity hotspots for conservation priorities. Nature 403: 853-858.

Oksanen J, Blanchet FG, Friendly M, Kindt R, Legendre P, McGlinn D, Minchin PR, O'Hara RB, Simpson GL, Solymos P, Stevens MHH, Szoecs E, Wagner H. 2017. Community Ecology Package Version 2.4-3. https://cran.r-project.org, https://github.com/vegandevs/vegan.

Prawiroatmodjo S Kartawinata K. 2014. Floristic diversity and structural characteristics of the mangrove forests of Raja Ampat West Papua Indonesia. Reinwardtia 14 (1): 171-180.

Purwaningsih, Polosakan R, Yusuf R, Kartawinata K. 2017. Phytosociological study of the montane forest on the south slope of Mt. Wilis, East Java, Indonesia. Reinwardtia 16 (1): 31-45.

R Core Team. 2017. R: A language and environment for statistical computing. http://www..R-project.org/

Reddy CS, Babar S, Amarnath G, Pattanaik C. 2011. Structure and floristic composition of tree stand in tropical forest in the Eastern Ghats of northern Andhra Pradesh, India. J For Res 22 (4): 491-500. 
Rosleine D, Suzuki E, Sundawiati A, Septiana W, Ekawati D. 2014. The effect of land-use history on natural forest rehabilitation at corridor area of Gunung Salak Halimun National Park, West Java Indonesia. Reinwardtia 14 (1): 85-99.

Rozak AH, Astutik S, Mutaqien Z, Widyatmoko D, Sulistyawati, E. 2016. Kekayaan jenis pohon di hutan Taman Nasional Gunung Gede Pangrango, Jawa Barat. Jurnal Penelitian Hutan dan Konservasi Alam 13 (1): 1-14. [Indonesian].

Rozak AH, Gunawan H. 2015. Altitudinal gradient affects on trees and stands attributes in Mount Ciremai National Park, West Java, Indonesia. Jurnal Penelitian Kehutanan Wallacea 4 (2): 93-99. [Indonesian]

Sadili A, Kartawinata K, Soedjito H, Samba EN. 2018. Tree species diversity in a pristine montane forest previously untouched by human activities in Foja Mountains Papua Indonesia. Reinwardtia 17 (2) 133-154.

Salvaña FRP, Lopez CKC, Mangaoang CC, Bretaña BLP. 2019. Short Communication: Diversity and community structure of trees in two forest types in Mt. Apo Natural Park (MANP), Philippines. Biodiversitas 20: 1794-1801

Sekercioglu CH. 2010. Ecosystem functions and services. In Sodhi NS, Ehrlich PR (eds.). Conservation Biology for All. Oxford University Press, UK.

Senthilkumar N, Murugesan S. 2012. Bioprospecting the renewable forest resources: An overview. Current Biotica 5 (4): 522-540.

Siregar M, Undaharta NKE. 2018. Tree standing dynamics after 30 years in a secondary forest of Bali, Indonesia. Biodiversitas 19 (1): 22-30.

Slik JWF, Aiba SI, Brearley FQ, Cannon CH, Forshed O, Kitayama K, Nagamasu H, Nilus R, Payne J, Paoli G, Poulsen AD, Raes N, Sheil D, Sidiyasa K, Suzuki E, van Valkenburg JLCH. 2010. Environmental correlates of tree biomass, basal area, wood specific gravity and stem density gradients in Borneo's tropical forests: Forest carbon and structure gradients. Global Ecol Biogeogr 19 (1): 50-60.

Sulistyawati E, Nasution T, Rosleine D, Putra DC. 2018. Tree community structure and composition of a one-hectare permanent Plot in the Montane Zone of Mount Kerinci, Kerinci Seblat National Park, Jambi. Journal of Mathematical and Fundamental Sciences 50 (3): 315-331.

Susilo A. 2018. Asosiasi jenis-jenis pohon dominan di Cagar Alam Gunung Tilu. Procceding Biology Education Conference 15 (1): 813817. [Indonesia].

The Angiosperm Phylogeny Group. 2016. An update of the Angiosperm Phylogeny Group classification for the orders and families of flowering plants: APG IV. Bot J Linn Soc 181 (1): 1-20.

Tsujino R, Yumoto T, Kitamura S, Djamaluddin I, Darnaedi D. 2016. History of forest loss and degradation in Indonesia. Land Use Pol 57: 335-347.

Wagner S, Fischer H, Huth F. 2011. Canopy effects on vegetation caused by harvesting and regeneration treatments. Eur J Forest Res 130: 1740 .

Zhu H, Yong C, Zhou S, Wang H, Y Lichun. 2015. Vegetation, floristic composition and species diversity in a tropical mountain nature reserve in southern Yunnan, SW China, with implication for conservation. Trop Conserv Sci 8 (2): 528-546.

Zuhri M, Mutaqien Z. 2013. The spread of non-native plant species collection of Cibodas Botanical Garden into Mt. Gede Pangrango National Park. J Trop Life Sci 3 (2): 74-82.

Zuhri M, Mutaqien Z, Nurdiana DR, Destri, Nudin, Djuanda. 2018. Vegetasi tumbuhan pada kawasan tepi hutan Taman Nasional Gunung Gede Pangrango yang berbatasan dengan Kebun Raya Cibodas. Biogenesis 6 (2): 105-114. [Indonesian] 